\title{
TRUSS JOINT WITH POSITIVE ECCENTRICITY EXPERIMENTAL RESEARCH
}

\author{
Małgorzata GORDZIEJ-ZAGÓROWSKA, Elżbieta URBAŃSKA- \\ GALEWSKA ${ }^{1}$, Patryk DENIZIAK, Łukasz PYRZOWSKI \\ Gdansk University of Technology, Gdańsk, Poland
}

\begin{abstract}
Due to the technological reasons in modern lightweight steel trusses, fabricated from coldformed sections, positive eccentricities appear in the truss nodes what induce additional forces in the truss chords. To account for the real load-carrying capacity of truss node area the steel structure research in scale 1:1 were conducted. The experiments consisted of two parts: preliminary and proper one, when conclusions from the first part were applied. Carrying out preliminary studies helped to identify of the research station drawbacks and eliminate most of them, what ensure the appropriate research results. The initial numerical analysis were also conducted what was presented in the paper.
\end{abstract}

Keywords: steel structure, thin-walled structures, cold-formed sections, eccentricities, truss, experimental research

\section{INTRODUCTION}

\subsection{General}

Interest in lightweight steel structures made from cold-formed sections, due to their many advantages is growing year on year. A lot of experimental studies which constitute the basis for numerical analysis are being conducted and new standards are being elaborated all over the world $[1,5,8,10,11]$. Designers put

\footnotetext{
${ }^{1}$ Corresponding author: Gdansk University of Technology, Department of Metal Structures and Construction Management, G. Narutowicza st 11/12, 80-233 Gdańsk, Poland, e-mail: ugalew@pg.gda.pl, tel.:+483471751
} 
more and more emphasis on the rational development of both the elements crosssections and designed with these elements thin-walled structures. The aim of this paper is to present the methodology of proceeding with the preparation of experimental studies mapping the behaviour of truss elements made of coldformed sections and research results presentation.

\subsection{Research problem}

Research issue concerns design solution used in structural systems of single storey steel buildings made of cold-formed open cross-sections as a whole. In the construction of a typical, mono-pitch, trapezium lattice girder, assuming a fixed spacing between the nods, the angle of inclination of brace members change due to technological reasons. The angle increase causes the appearance of the positive eccentricity in the truss joint and therefore occurrence of the bending moment in the presence of shear. In accordance with the current state of knowledge [7], when dimensioning the lattice girder's chord, one should take into consideration the eccentricity occurrence that leads to the necessity for local increase in the chord's section in the joint area. Practically, this is done by strengthening the chords through the use of channel-section covers (Fig. 1) or by increasing of the crosssection wall thickness over the entire length of the element.

Both solutions are uneconomical what caused that research on real load-carrying capacity of the compressed and bent chord of the lattice girder made of coldformed open cross-sections was undertaken.

The study aimed to clarify whether the bolted connection of the brace members to the walls of the hat cross-section chord locally stiffen the joint area providing increase of its capacity relative to this determined by traditional methods.

a)

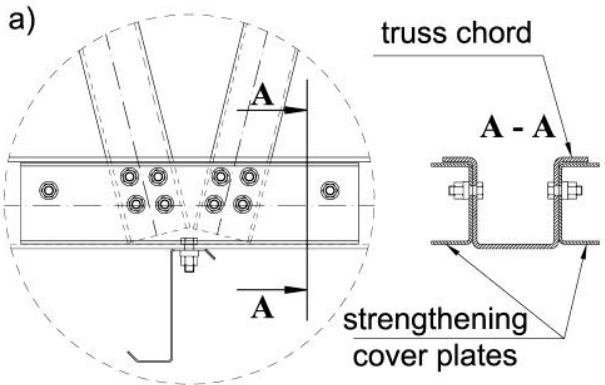

b)

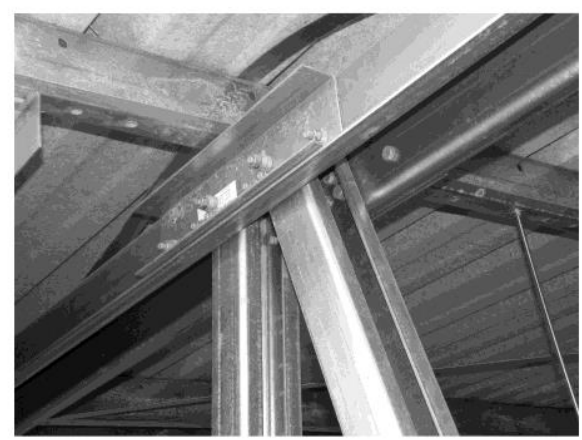

Fig. 1. Node with strengthening cover plates: a) view and cross-section, b) Photo. M. Gordziej - Zagórowska [2]

Preliminary numerical model of the structure designed for research purposes was created before experimental studies. The aim of the preliminary numerical 
analysis was to verify both the geometry and the static research model, as well as to confirm the research assumptions. In the future, the research results will constitute the basis for the preliminary numerical model validation.

\section{PRELIMINARY NUMERICAL ANALYSIS}

\subsection{Research model}

The stability test of the compressed member, additionally loaded with a local bending moment was planned in a 1:1 scale. To realise this goal the research model of lattice girder section with dimensions $2000 \times 1315 \mathrm{~mm}$ was designed from thin-walled cold-formed open cross-sections (Fig. 2). Cold-formed elements made of galvanized steel S350GD with zinc surface Z275MA were applied. The chords were designed from the hat-section $\mathrm{H} 39 / 117 / 106 / 117 / 39 \times 2$, and the brace members from channel-sections C 17/75/100/75/17x2. All the connections within the truss joints were designed as bolted. Fig. 2 a exemplifies location of the connections which are made with six M12 kl. 8.8 bolts (three bolts on each hatsection web).

The proper construction of the nodes, due to the lack of space for bolts, demanded shifting the brace members ends outside, what caused the positive bending moment appearance in the node. The research model was loaded with two concentrated forces (Fig. 2b). Force $H$ induced pressure on the lower chord, while force $P$ caused local bending of the lower chord in the joint area.
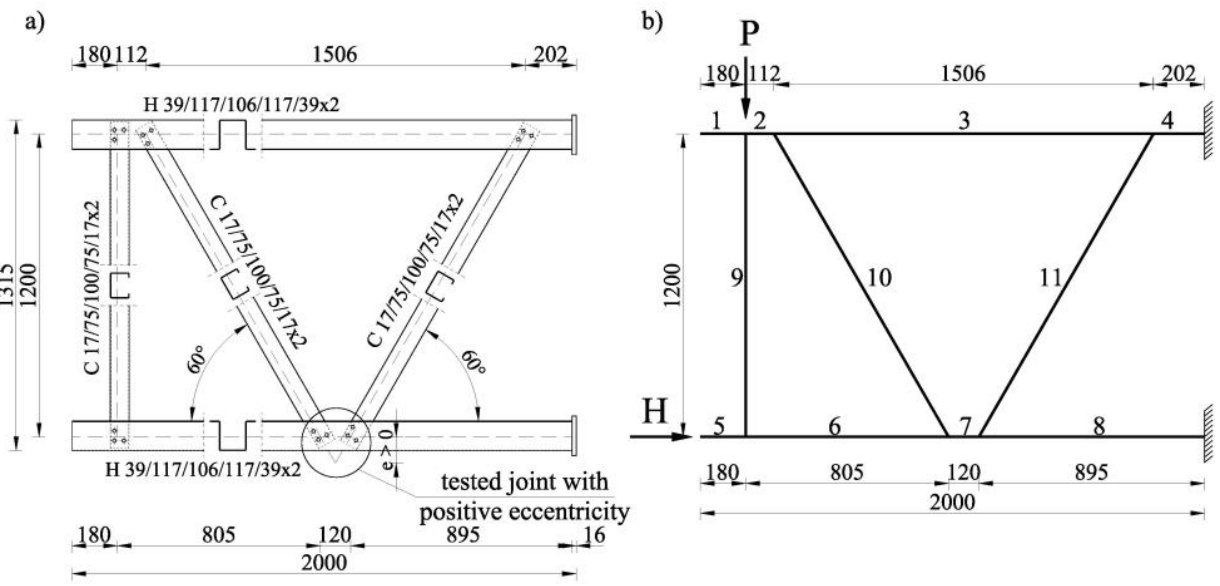

Fig. 2. Research model: a) view of the construction, b) static scheme [3] 


\subsection{Results of the preliminary numerical analysis}

On the basis of the research model presented above appropriate numerical model with the use of Marc Mentat - MSC Software was built. For computational modeling 4-node 'thin shell-139' elements were used. This is the thin shell element with global displacements and rotations as degrees of freedom. Bilinear interpolation is used for the coordinates, displacements and the rotations. The membrane strains are obtained from the displacement field; the curvatures from the rotation field [4].

The way of preliminary numerical model building, assumed models of material features and assumptions concerning way of members connections in truss nodes were presented in [3] in detail. The purpose of a preliminary numerical analysis was to determine the member's cross-sections shape (corresponding to the real structure), the proper static scheme and sequence of structure loading. The model parameters were selected so as to reconstruct the stress state in a real truss with the eccentric joint. Due to the time-consuming nature of the process of numerical modelling, welded joints were assumed in the preliminary analysis. Welds were made with the use of rigid surface elements (3- and 4-node), to assure that they will play role of non-deformable connections under loading. The complicated issue of the joints flexibility in this type of connections will be developed during further numerical analysis with the use of relations established by Zaharia \& Dubina [12], Słowiński at al. [9].

Preliminary numerical analyses were conducted for two types of truss models: sensitive and insensitive to local instability (in accordance with the classification of cross-section). Insensitive models were done from $5 \mathrm{~mm}$ thick shell elements (brace members) and $6 \mathrm{~mm}$ thick (chords) thereby creating class 1 cross-section (according to EN 1993-1-1, 2006 [6]). Models sensitive to local instability were performed from 2 and $3 \mathrm{~mm}$ thick shell elements in two variants (Table 1).

Table 1. Types of analyses

\begin{tabular}{|c|c|c|c|c|}
\hline \multirow{2}{*}{\multicolumn{2}{|c|}{ Type of elements }} & \multicolumn{2}{c|}{ Types of models } \\
\cline { 3 - 5 } & $\begin{array}{c}\text { insensitive } \\
\text { to local instability }\end{array}$ & \multicolumn{2}{c|}{$\begin{array}{c}\text { sensitive } \\
\text { to local instability }\end{array}$} \\
\hline \multirow{2}{*}{$\begin{array}{c}\text { member } \\
\text { wall } \\
\text { thickness }\end{array}$} & $\begin{array}{c}\text { brace members } \\
\text { C } 17 / 75 / 100 / 75 / 17\end{array}$ & $5 \mathrm{~mm}$ & $2 \mathrm{~mm}$ & $2 \mathrm{~mm}$ \\
\cline { 2 - 5 } & $\begin{array}{c}\text { chords } 39 / 117 / 106 / 117 / 39 \\
\text { Analysis code: }\end{array}$ & $6 \mathrm{~mm}$ & $3 \mathrm{~mm}$ & $2 \mathrm{~mm}$ \\
\hline \multicolumn{2}{|c|}{ An } & $\mathbf{, 5 / 6 "}$ &, $\mathbf{2 / 3} \%$ &, $\mathbf{2 / 2} \%$ \\
\hline
\end{tabular}


Next, all types of models were submitted for three types of analysis: Mechanically Nonlinear Analysis (MNA), Geometrically Nonlinear Analysis (GNA) and Geometrically and Mechanically Nonlinear Analysis (GMNA). Conducted analysis confirmed, that 3 and $2 \mathrm{~mm}$ thick walls are sensitive to local instabilities. Outcomes of these analyses were presented in detail in the paper [2], [3]. Furthermore, the results confirmed that research hypothesis conceived by authors is valid as not only none of the obtained structure failure models occurred in the compressed and bending area of the hat section but also the increase in material effort was not observed. The model with $2 \mathrm{~mm}$ thick walls (both chords and brace members) sensitive to local instability was chosen for further experimental studies. Numerical analyses were also a tool to determine the approximate maximum value of the compression force $H$ and bending force $P$, necessary at the experimental stage.

\section{PRELIMINARY TEST}

\subsection{Research station}

In order to conduct the experimental research the special stand, presented in Fig. 3 was designed. The following conditions were taken into consideration when the shape of the laboratory stand was elaborated:

- due to the limitations of the technical possibilities within the laboratory the research model had been turn by $90^{\circ}$ during experimental phase (dead load of the construction was assumed as an negligible);

- the supporting joints and the places where the concentrated forces were applied, were properly strengthen;

- to ensure a free movement of the "C" joint under the bending force $P$ (Fig. 4), the introducing of the compression force $H$ couldn't been done through an actuator, as such a solution would result in the change of the static scheme of the research model that was anchored as an cantilever. In order to achieve the free displacement of the truss in the "C" joint, a special compression head was designed (Fig. 5).

With respect to above conditions the compression force $\mathrm{H}$ and bending force $\mathrm{P}$ were applied respectively by means of two turnbuckles (Fig. 5) and an expansion bolt (Fig. 3).

The value of the bending force $\mathrm{P}$ was registered by a dynamometer N.B.C. Elettronica, with a nominal range of $\pm 100 \mathrm{kN}$ while the value of the compression force $H$ was measured with a dynamometer CZAH CT-25 with nominal range of $250 \mathrm{kN}$. The last one was located between the compression head and the compressed section of the tested model (Fig. 6). 


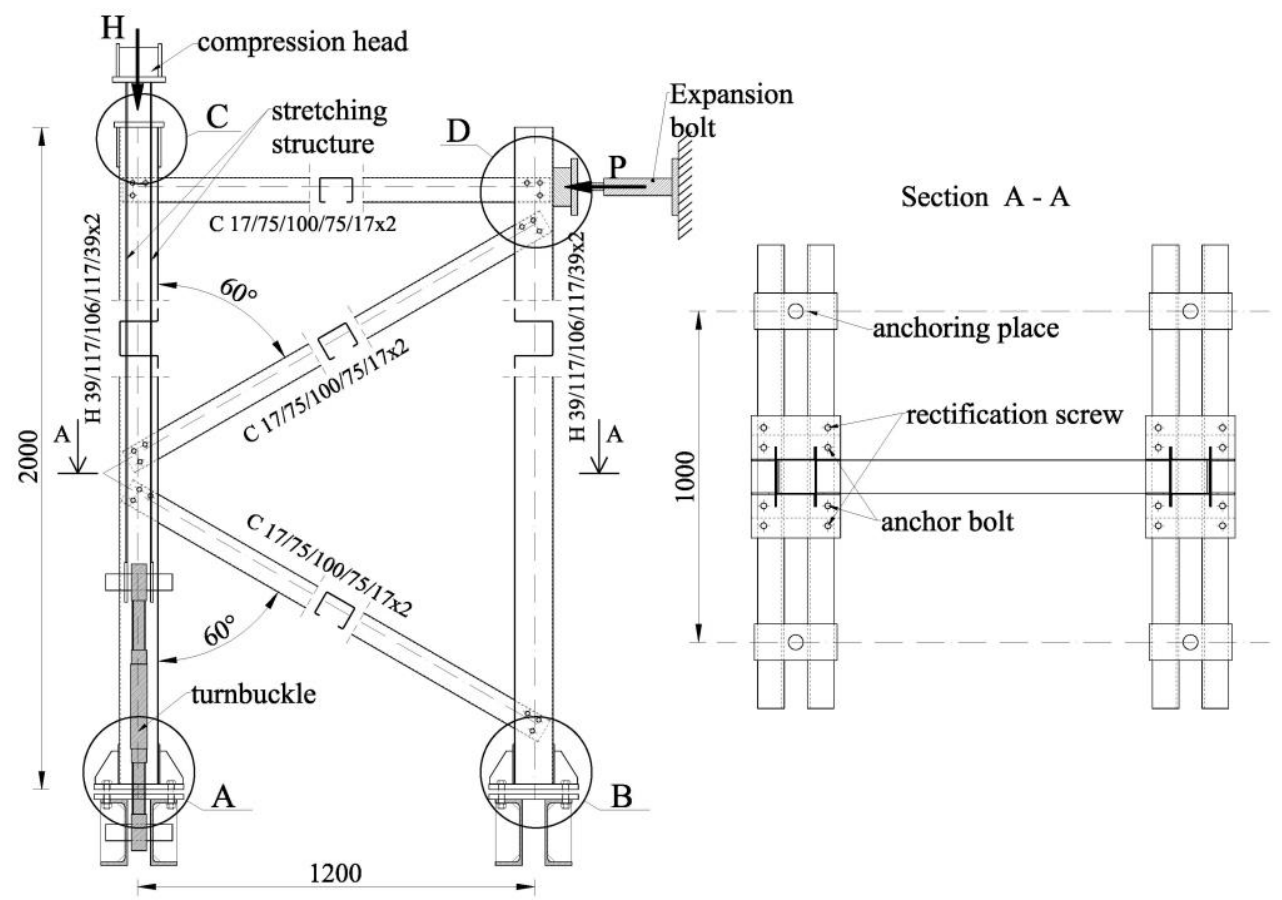

Fig. 3. Design of the first version of the research station [3]

a)

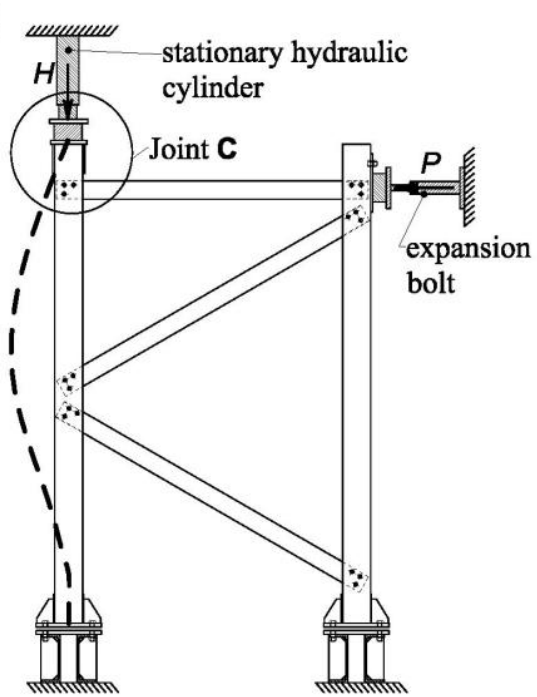

b)

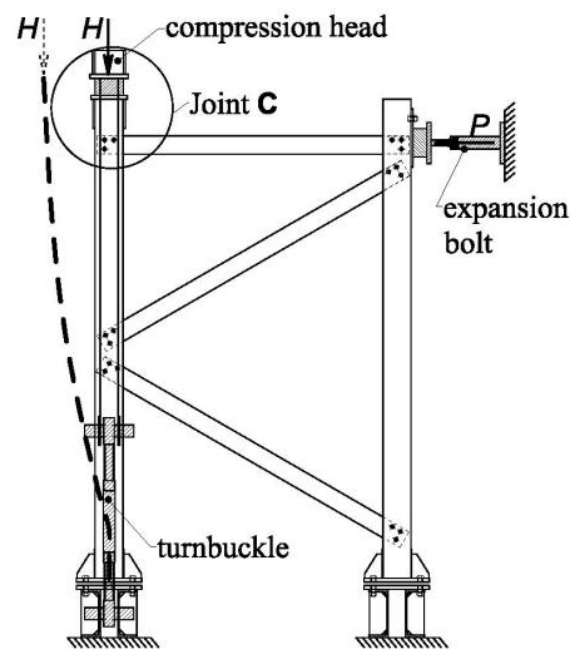

Fig. 4. Research model scheme of work when using: a) stationary hydraulic cylinder, b) compression head 

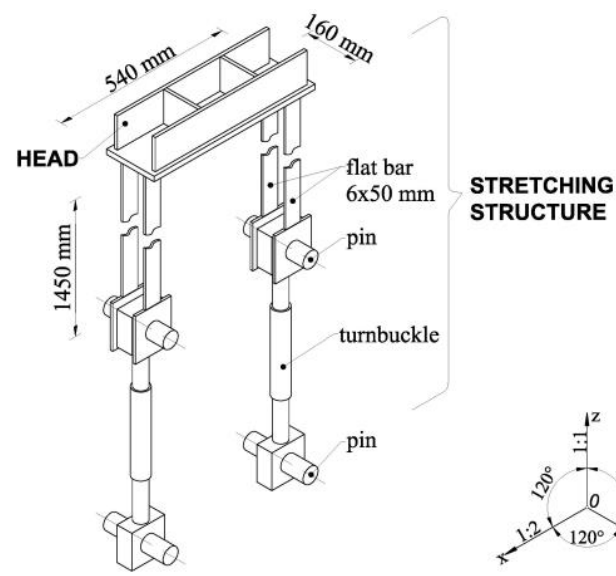

STRUCTURE

Fig. 5. Design of the compression head - isometric view

Three inductive sensors with measuring range of $\pm 100 \mathrm{~mm}$ located on the structure in accordance with the scheme presented in Fig. 6 were used during the experimental test. The inductive sensors $\mathrm{X}$ and $\mathrm{Y}$ measured the movements of the research model in the plane of bending while the sensor $\mathrm{Z}$ measured the movement from the bending axis. For measurement of the strains, strain gauges LY11-6/120A were applied in four measuring cross-sections. Three crosssections were located on the compressed hat-section chord respectively: 1-1 above the objective joint, 2-2 in the axis of the joint and 3-3 below the joint. The fourth cross-section was on the brace member as it is shown in Fig. 6.

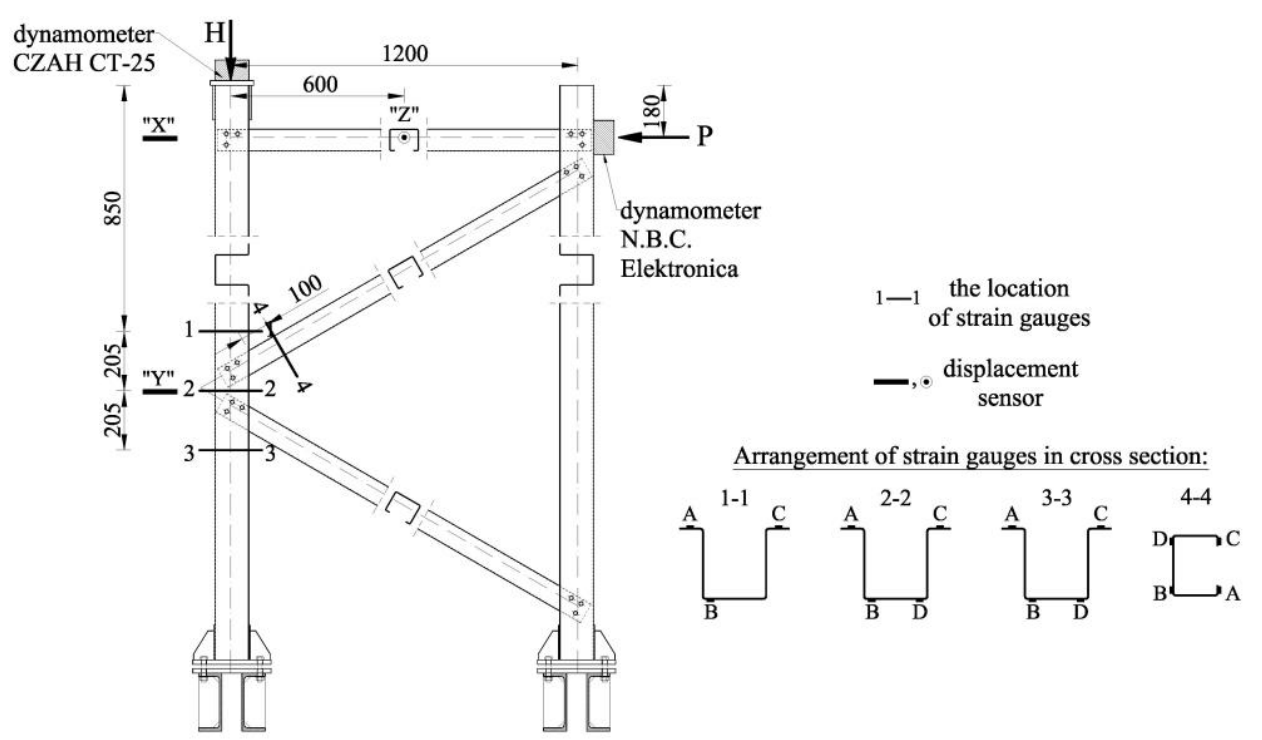

Fig. 6. Placement of strain gauges and inductive sensors on the tested model [3] 


\subsection{Results of the preparatory experimental tests}

Prior to proper testing of the research model a static uniaxial tensile test for steel material was carried out on a ZWICK / ROELL Z400 machine with $50 \mathrm{kN}$ head to achieve proof stress, Young's modulus and real stress-strain relationship. Next, the loading of the research model started. At first the compression force $H$ was applied gradually increasing its value until reaching $115 \mathrm{kN}$. The value of the compression force $H$ was not changed since that moment. Next, the introduction of the bending force $P$ began. As can be seen in the loading diagram in time presented in Fig. 7 the increase in the value of the bending force $P$ caused simultaneous decrease in the value of the compression force $H$.

It should be noted that maintaining the compression force $H$ at the constant level while introduce the bending load (force $P$ ) was not possible due to the instrumentation used. A detailed description of the test was the theme of the paper [3].

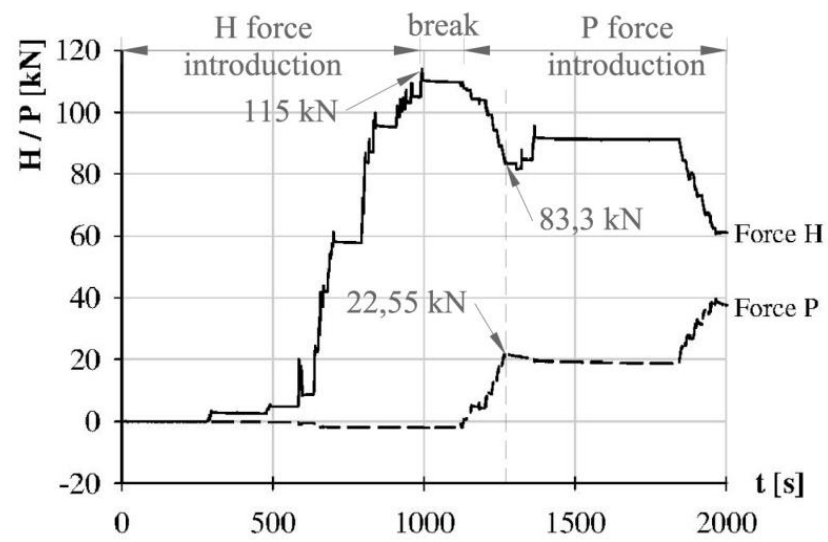

Fig. 7. The loading diagram in time (concentrated forces $\mathrm{H}$ and $\mathrm{P}$ ) [3]

Strains measured in cross-sections 1-1, 2-2 and 3-3 were the basis of the normal stresses quantification presented in Fig. 8. The results from the strain gauge "A" showed that introduction of the compression force $H$ caused torsion of the compressed chord of the research model. This unintentional torsion was pointed out throughout all three measurement sections. Introduction of the bending force $P$ caused further differentiation of strains resulting in its reduction or increase in particular cross-sections.

Moreover, displacement control conducted during tensioning showed that the researched model had moved from the axis of the compression and bending [3] already at the moment of application of the compression force $H$. This was a consequence of the way of the compression force $H$ introduction what resulted in the torsion of the tested element. Furthermore, all the measured displacements were much higher than those calculated by preliminary numerical analysis. 
a)

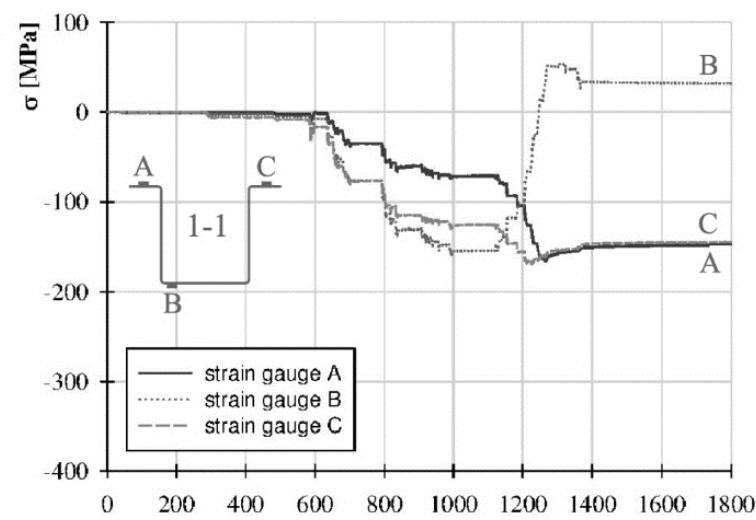

b)

$\mathbf{t}[\mathrm{s}]$

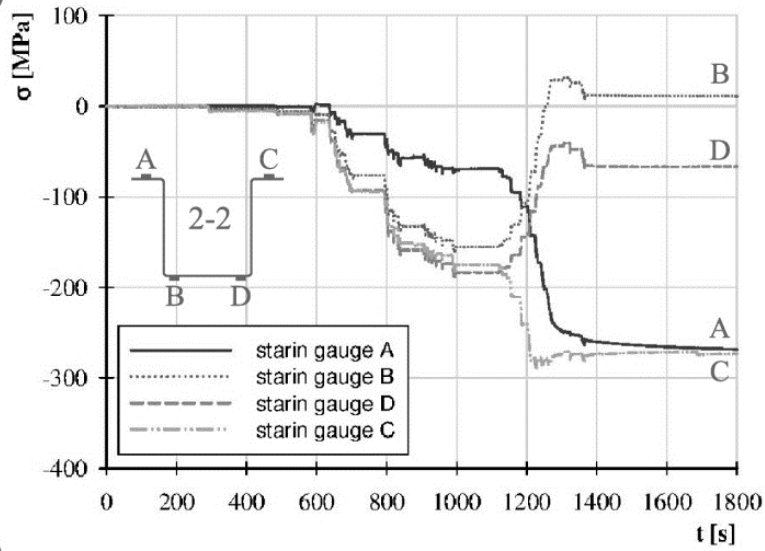

c)

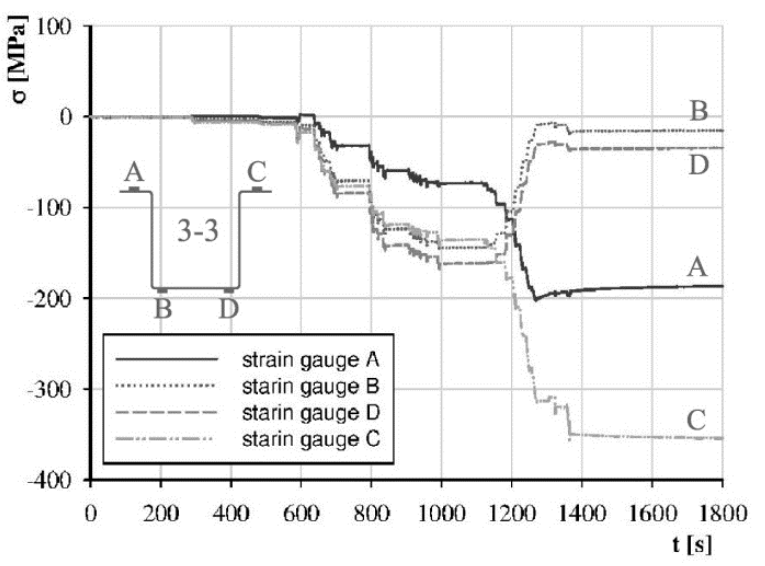

Fig. 8. Graph of normal stresses in time obtained on the basis of measured strains in cross-sections: a) 1-1, b) 2-2, c) 3-3. [3] 


\subsection{Conclusions}

The conducted research of the first model and obtained results allowed for verification of geometry and static scheme of the truss research model as well as the design of the research stand. It was recognized, that structure of the research model was correct and did not require any changes. However, it was essential to introduce changes to the construction of the first version of the research stand prior to testing the remaining 5-five research models. Firstly, the structure of the compression head should be changed in the way to protect the compressed truss chord from random torsion. Next, the significant limitation of the model displacements (from the bending plane) should be ensured.

\section{EXPERIMENTAL RESEARCH}

\subsection{Research station modification}

The design of the improved research station with the changes marked in the red color is presented in Fig. 9 and 10.

The change of the way of introducing the force $H$ to eliminate random torsion of the compressed truss chord during experiments was the primarily authors concern. In the first version of the laboratory stand the compression force $H$ was introduced by the help of the compression head structure presented in Fig. 5.

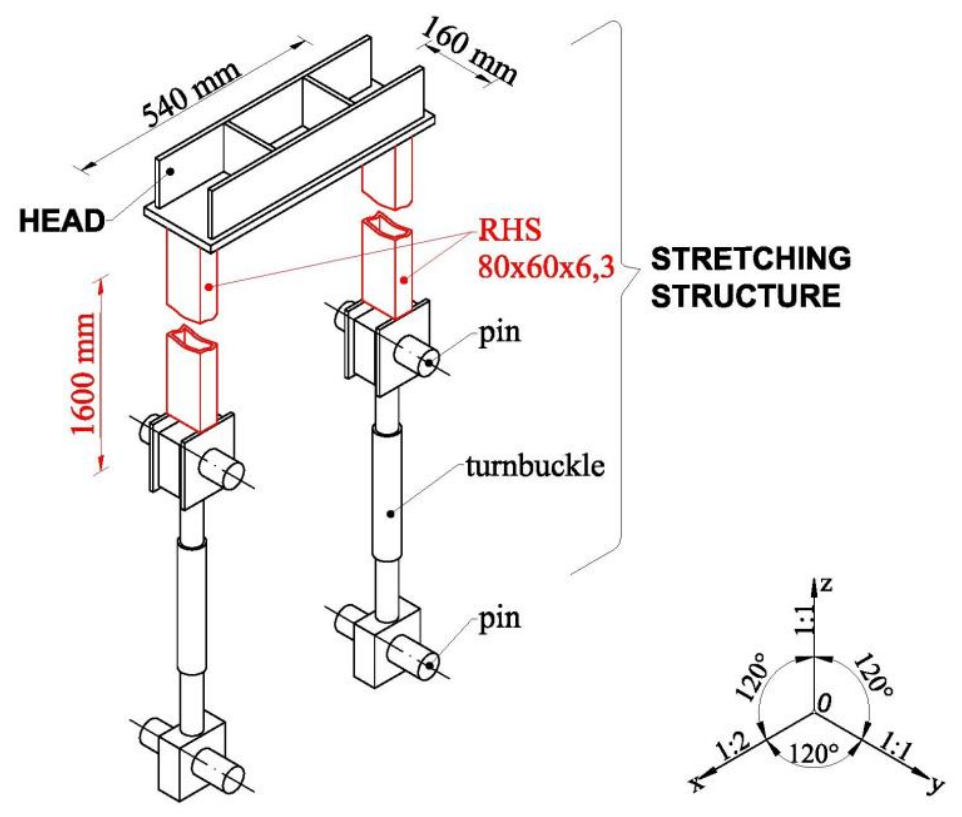

Fig. 9. Design of the final version of the compression head 

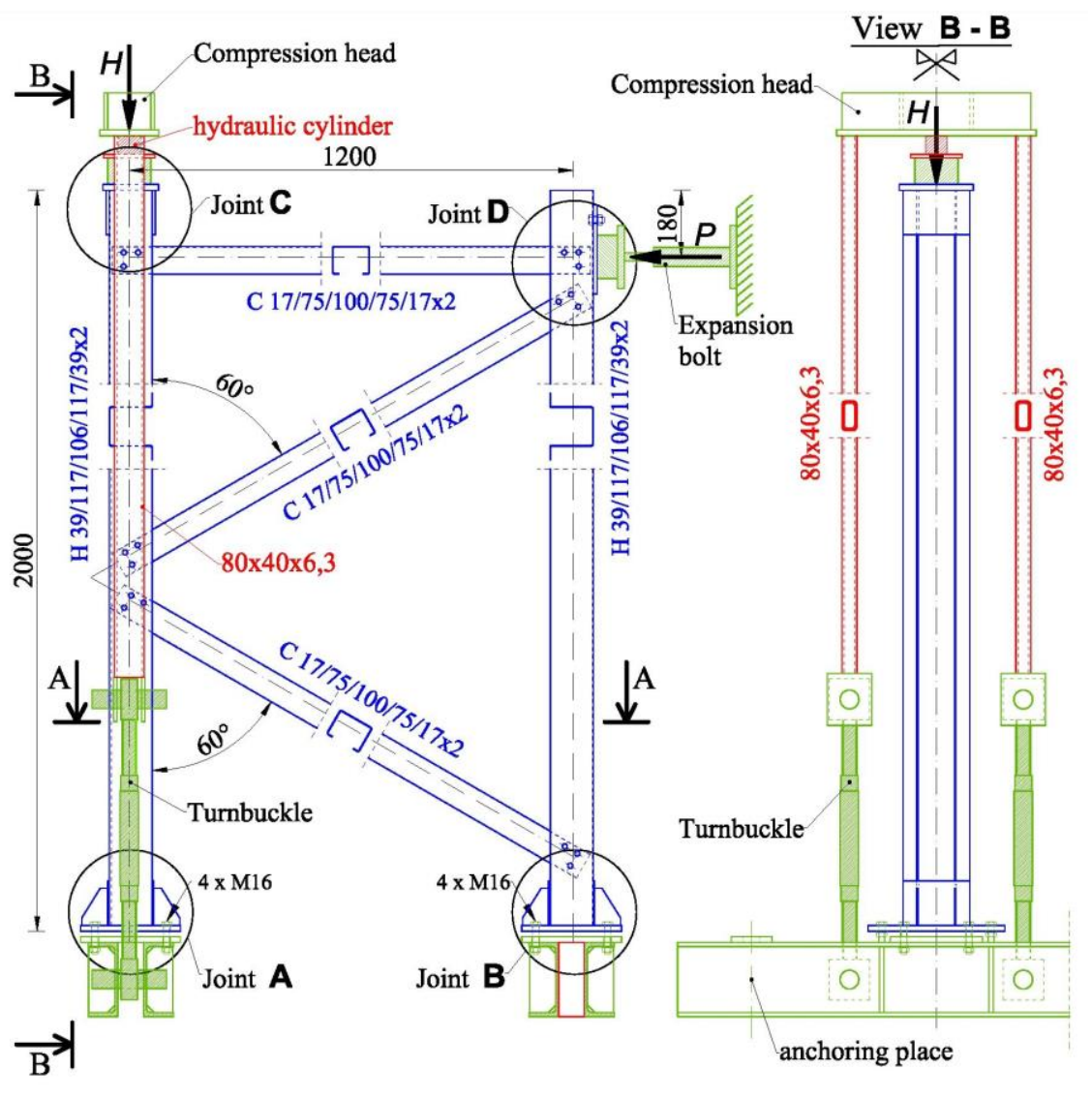

Section A - A

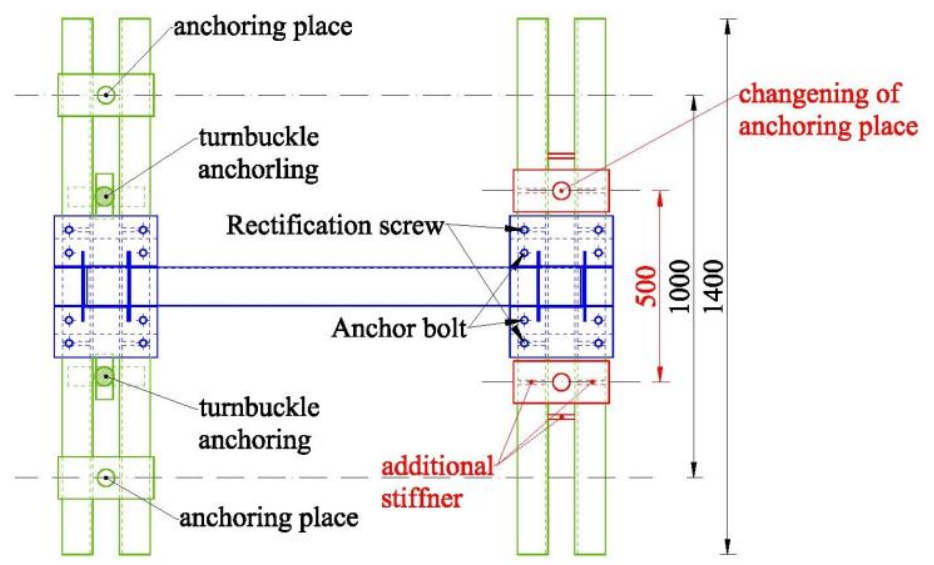

Fig. 10. Design of the modificated version of the research station 
Stretching elements were tensioned by means of two hand-tightened turnbuckles. At the new version of the stand the force $H$ was applied by means of low profile hydraulic cylinder (BVA HF2005) with a capacity of 20 tons, which was located between flat plate of the compression head and dynamometer (Fig. 11), exactly in the hat section center of gravity axis. Thereby the possibility of unequal uploading of the model was eliminated, as it was when two turnbuckles were used. The proposed modification ensured the free movement of the joint "C" during uploading as in the first version.

Anyway, the turnbuckles were left in the compression head structure to use them for the leveling of the compression head and for adjusting and alignment the initial tension of the stretching elements. Additionally, it was decided to exchange the flat bars which were parts of stretching elements into rectangular hollow section $80 \times 40 \times 6,3$ to ensure their higher torsional stiffness (Fig. 9).

The consecutive modification of the laboratory stand aims at limitating of the stand excessive rotation and displacements. The strengthening of the stand anchoring beams fixed to special anchoring rails in the laboratory floor plate was necessary. Additional stiffeners of the pulled anchoring beam under joint "B" were provided and anchoring bolts spacing was reduced (Fig. 10).

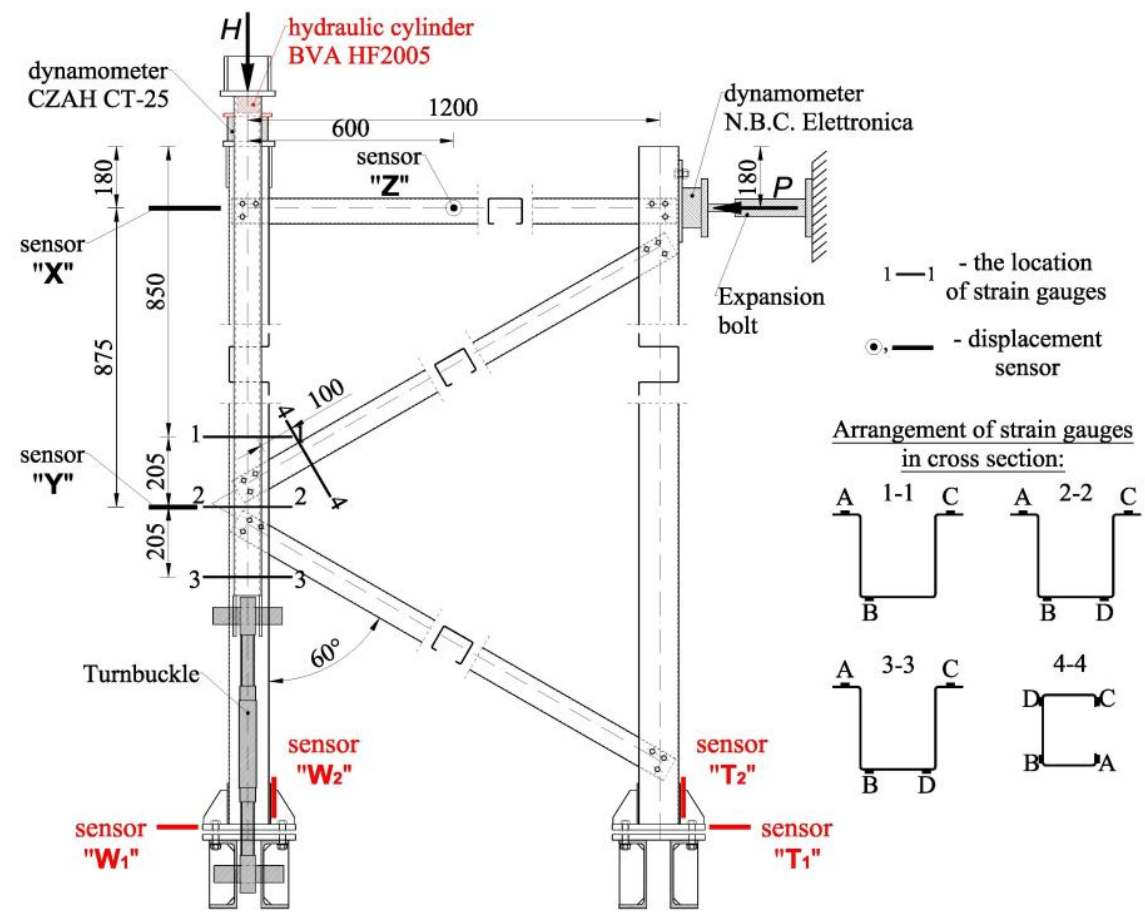

Fig. 11. Placement of measurement equipment on the research model (introduced changes are marked in red colour) 
The way of model loading by bending force $P$ and recording its value were not changed as the number and location of strain gauges.

Nevertheless authors decided to record measurements of possible horizontal and vertical displacements of support joints " $A$ " and " $B$ " to determine real stiffness of the base joint. To that end, additional three inductive sensors $\left(\mathrm{W}_{1}, \mathrm{~T}_{1}, \mathrm{~T}_{2}\right)$ with measuring range of $\pm 100 \mathrm{~mm}$ and one dial indicator $\left(\mathrm{W}_{2}\right)$ also with measuring range of $\pm 100 \mathrm{~mm}$ were applied. Location of the whole measuring equipment on the research model after changes is presented in the Fig. 11.

The introduction of all the above changes during the modification of the laboratory stand made it possible to eliminate most of the drawbacks of the preliminary test.

\subsection{Results of experimental research}

The laboratory tests of 5 models in scale 1:1 were conducted on the modificated research station. Research methodology was the same as at the first time. Strains values of the four indicated cross-sections in the area of the analysed node (Fig. 11), under the applied load were recorded continuously (in real time).

Graphs of normal stresses in time obtained on the basis of strains measured in the all cross-sections and registered during the model No. 4 research are presented in the Fig. 12.

Values of the stresses were stated based upon measured strains and with the use the mean value Young's modulus determined on the basis of the uniaxial tensile test for steel material of channel-sections and hat-sections equal respectively $199 \mathrm{GPa}$ and $210 \mathrm{GPa}$.

As can be seen in Fig. 12 during a first loading step, that is during the introduction of compression force $H$ the coincidence of readings from strain gauges $\mathrm{A}, \mathrm{B}, \mathrm{C}$ and $\mathrm{D}$ in the all measurement sections occurred. This is the evidence of the uniform distribution of the stresses in the compressed sections. It should also be noted that no shape deformations were observed during the first phase of research models loading. At the beginning of the second phase of loading (before a loss of stability), symmetrical increases (strain gauges A and C) or decreases (strain gauges $\mathrm{B}$ and D) of cross-section deformations, with respect to the local axis $y-y$, were observed. Therefore, the obtained results substantiated the purposefulness of carrying out modification of the research station first version. However, within the scope of the loss of the local stability it was pointed out that shape deformations had lost their symmetrical forms (as can be seen in Fig. 12). 
a)

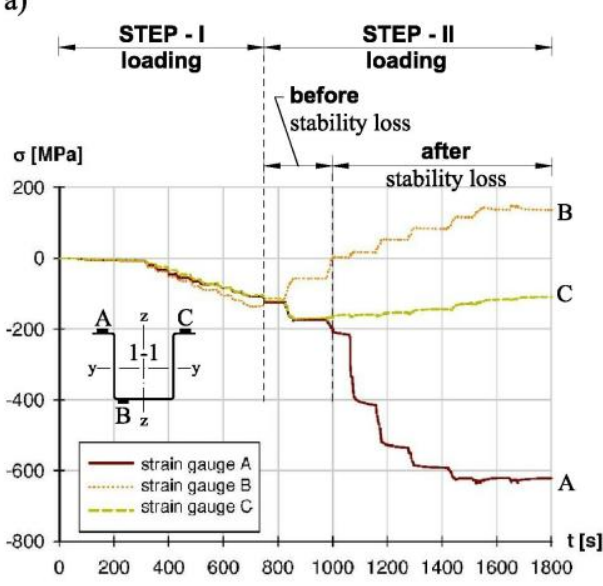

c)
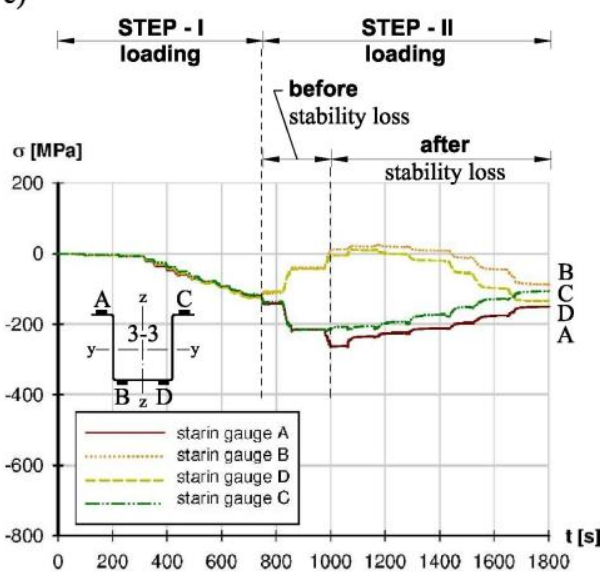

b)

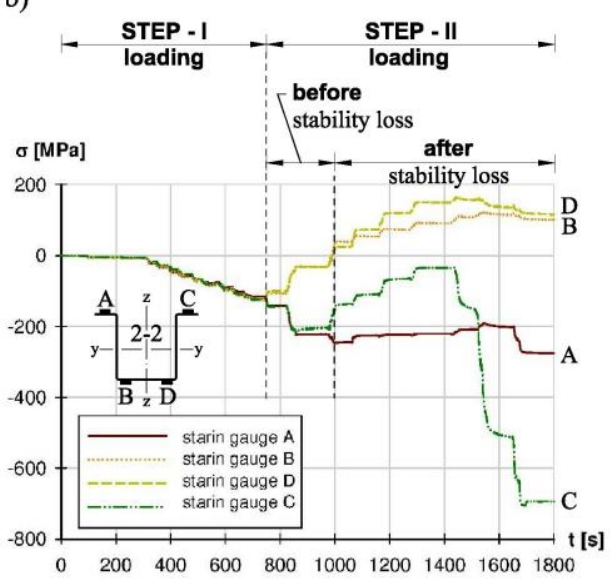

d)

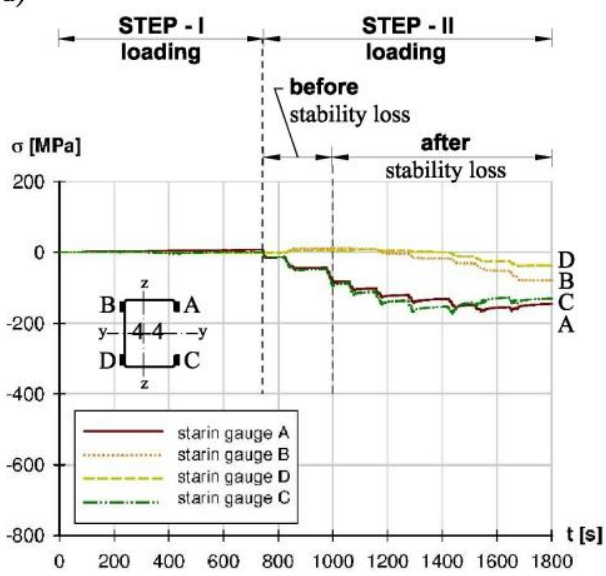

Fig. 12. Graph of normal stresses in time obtained on the basis of strains measured in cross-sections respectively: a) 1-1, b) 2-2, c) 3-3, d) 4-4, (from the model of No. 4)

The outstand elements of the cross sections (free flanges) had different directions of the strains (measured by strain gauges $\mathrm{A}$ and $\mathrm{C}$ ) what constitutes the evidence of the typical halve-wave shape local buckling occurrence. Lack of deformations symmetry with respect to a local axis $\mathrm{z}-\mathrm{Z}$ is caused by various inherent imperfections of steel structures Buckling forms of the hat section and the channel-section observed during the research are presented respectively in Fig. 13a) and Fig. 13b). These deformations occurred at the final stage of the load $\left(\mathrm{P}=40 \mathrm{kN}, \mathrm{H}_{\mathrm{odp}}=55 \mathrm{kN}\right)$. 

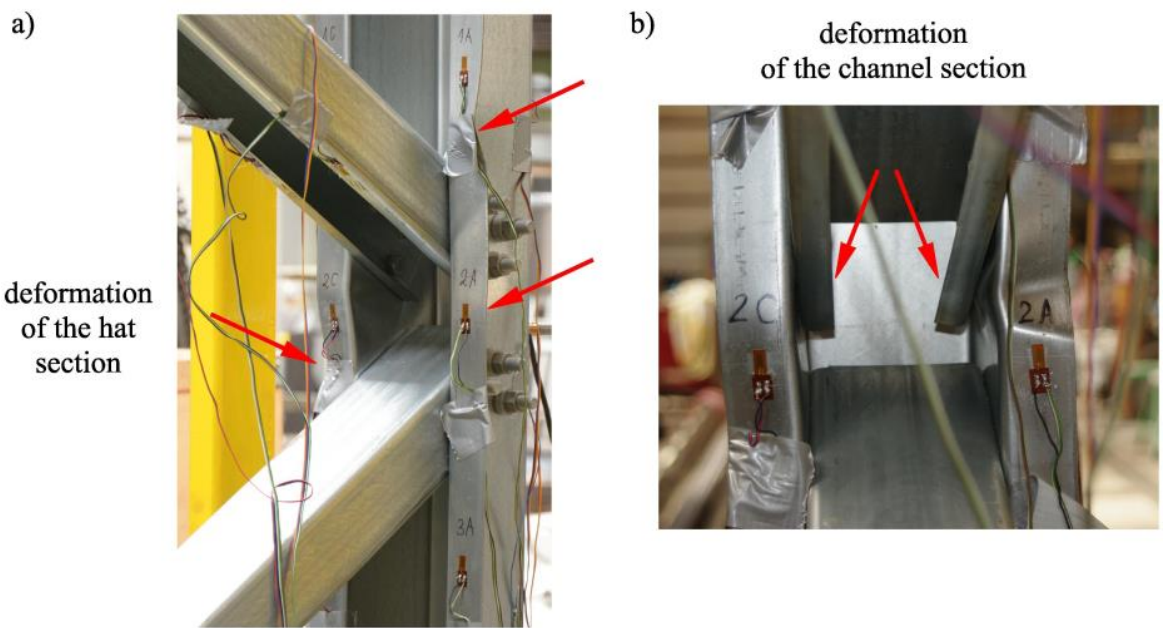

Fig. 13. Buckling forms of: a) the hat section flange, b) distorsion of the channel-section (for the final stage of the load)

Values of the bending force $P$, and the corresponding compression force $H$ the presence of which initiated the beginning of the stability losing in the area of the analysed joint are shown in Table 2 . Beginning of instability always started at the cross-section 2-2 and the deformations were enlarging until failure while the loading was growing.

Moreover it had been observed that described above research stand modifications caused significant decrease of its displacements from the truss bending plane, what was recorded by sensor $Z$. Measured displacement values were in the range from $-2,28 \mathrm{~mm}$ to $4,65 \mathrm{~mm}$, what was recognized as negligible.

However, values of horizontal and vertical displacements of the support joints "A" and "B" proved that modified research stand structure did not ensure full rigidity of the base joints just as at the first version of the structure. Due to gained data, the real stiffens of the base joints will be applied in the foreseen advanced numerical analysis.

Table 2. Values of the forces $\mathrm{P}$ i $\mathrm{H}_{\text {cor }}$ initiated the beginning of the stability losing

\begin{tabular}{|c|c|c|}
\hline Research model number & Force $\mathbf{P}[\mathbf{k N}]$ & Force $\mathbf{H}_{\text {cor }}[\mathbf{k N}]$ \\
\hline Model $\mathbf{2}$ & 8,5 & 87 \\
\hline Model $\mathbf{3}$ & 7,7 & 89 \\
\hline Model $\mathbf{4}$ & 5,0 & 95 \\
\hline Model $\mathbf{5}$ & 6,7 & 87 \\
\hline Model $\mathbf{6}$ & 5,0 & 96 \\
\hline
\end{tabular}




\section{CONCLUSIONS}

Presented in the paper process of research station calibration exemplifies the importance of both the preliminary numerical analysis and the preliminary experiment. The former is helpful in designing the research station and research model. The latter helps to verify correctness of the project assumptions. While recognising the areas of errors researchers have a chance to remove them. The presented approach is time consuming but eventually provides the higher quality of achieved research results. In that case, the results gained after introduction of changes to the research stand and carrying out of the final tests on 5 models will constitute solid ground for validation of the numerical model of the analysed joint and will enable full verification of the research hypothesis, which will be presented in the next publication.

\section{REFERENCES}

1. Garstecki, A., Kąkol, W., Rzeszut, K.: Global and local stability analysis of thin-walled beams, in: Metal Structures: Design, Fabrication, Economy, edit. K. Jarmai, J.Farkas, Miscolc, Hungary, Millpress (2003), 61-66.

2. Gordziej-Zagórowska, M., Urbańska-Galewska, E., Jankowski R.: Modelling of truss with cold-formed section and positive eccentricity in the node, Structure and Environment, 4 (2014): 24-34.

3. Gordziej-Zagórowska, M., Urbańska-Galewska, E., Pyrzowski Ł., Deniziak P., A. Łukowicz: Preliminary experimental research on stability of truss' joint with positive eccentricity, in: Recent Progress in Steel and Composite Structures: Proceedings of the XIII International Conference on Metal Structures (ICMS 2016), edit. M. Giżejowski et.al., Zielona Góra, Taylor \& Francis Group, Balkema Book (2016), 425-432.

4. Marc 2013.1, Volume B: Element Library, MSC Software, program instruction, (2013).

5. Mądry, D.: Niestateczność miejscowa trapezowego przekroju zginanego z uwzględnieniem sprężystego utwierdzenia ścianek, Inżynieria i Budownictwo, 1 (2006): 55-58.

6. EN 1993-1-1. 2005. Eurocode 3: Design of steel structures - Part 1-1: General rules and rules for buildings.

7. EN 1993-1-8. 2005. Eurocode 3: Design of steel structures - Part 1-8: Design of joints.

8. Rzeszut, K., Garstecki, A.: Zagadnienia niestateczności prętów z ksztattowników giętych, Inżynieria i Budownictwo, 3 (2006) 166-169. 
9. Słowiński, K., Swierczyna, S., Wuwer, W., Zamorowski, J.: Podatność połaczeń zakładkowych w konstrukcjach stalowych z kształtowników giętych, Inżynieria i Budownictwo, 5-6 (2010): 327-331.

10. Szychowski, A.: The stability of eccentrically com-pressed thin plates with o longitudinal free edge and with stress variation in the longitudinal direction, Thin-Walled Structures, 46, 5 (2008): 494-505.

11. Szychowski, A.: Stability of cantilever walls of steel thin-walled bars with open cross-section, Thin-Walled Structures, 94 (2015): 348-358.

12. Zaharia, R., Dubina, D.: Stiffness of joints in bolted connected cold-formed steel trusses, Journal of Constructional Steel Research, 62, 3 (2006): 240-249.

\section{BADANIA EKSPERYMENTALNE WEZŁA KRATOWNICY Z MIMOŚRODEM DODATNIM}

\section{Streszczenie}

W nowoczesnych konstrukcjach stalowych dźwigarów kratownicowych, wykonywanych z kształtowników giętych na zimno, ze względów technologicznych w węzłach kratownic występują mimośrody dodatnie, które powodują powstanie dodatkowego zginania ze ścinaniem w rejonie węzła. W celu określenia rzeczywistej nośności takiego węzła przeprowadzono badania na modelach konstrukcji kratownicy w skali 1:1. Badania przeprowadzono $\mathrm{w}$ dwóch etapach: pierwszym wstępnym oraz drugim, w którym wykorzystano wnioski z etapu pierwszego. Przeprowadzenie badań wstępnych było pomocne w identyfikacji błędów oraz ich późniejszym usunięciu, co przyczyniło się do uzyskania poprawnych i wiarygodnych wyników badań. W artykule przedstawiono również wstępne analizy numeryczne badanego modelu kratownicy.

Słowa kluczowe: konstrukcje stalowe, konstrukcje cienkościenne, kształtowniki gięte na zimno, mimośrody, kratownice, badania eksperymentalne

Editor received the manuscript: 04.07.2016 